\title{
ANALISIS FAKTOR-FAKTOR YANG MEMPENGARUHI KEPUASAN KERJA APOTEKER DI KLINIK-KLINIK PRATAMA KOTA PEKANBARU
}

\author{
Erniza Pratiwi ${ }^{1 *}$, Fina Aryani ${ }^{1}$, Resa Enelia ${ }^{1}$ \\ ${ }^{1}$ Sekolah Tinggi Ilmu Farmasi Riau; Jalan Kamboja, Simpang Baru Panam, 28292 \\ E-mail: ernizapratiwi@gmail.com
}

\begin{abstract}
ABSTRAK
Setiap karyawan dalam suatu perusahaan perlu mendapatkan kepuasan dalam bekerja yang juga dapat berdampak pada peningkatan kinerja karyawan. Kepuasan kerja (job satisfaction) merupakan suatu sikap berupa refleksi dari perasaan karyawan terhadap keseluruhan pekerjaan yang terdiri dari bermacam-macam aspek. Seseorang yang puas dalam pekerjaannya akan memiliki motivasi, komitmen pada organisasi dan partisipasi kerja yang tinggi sehingga akan terus memperbaiki kinerja mereka. Tujuan dari penelitian ini adalah untuk mengetahui faktor-faktor apa sajakah yang mempengaruhi kepuasan kerja apoteker di klinik-klinik pratama Kota Pekanbaru. Penelitian ini merupakan penelitian deskriptif analitik dengan rancangan penelitian cross sectional dengan menggunakan kuesioner kepuasan kerja. Sampel dalam penelitian ini adalah apoteker yang bekerja diklinik-klinik pratama yang berjumlah 55 orang yang diambil dengan teknik simple random sampling. Hasil yang diperoleh menunjukkan bahwa faktor-faktor yang paling dominan mempengaruhi kepuasan kerja apoteker diklinik-klinik pratama kota pekanbaru adalah keamanan kerja (78,91\%), perlakuan adil (78,84\%), hubungan antara rekan kerja (78,04\%), gaji dan promosi $(77,30 \%)$, kondisi kerja $(77,16 \%)$ dan hubungan dengan pimpinan $(76,00 \%)$.
\end{abstract}

Kata kunci : Kepuasan Kerja; Apoteker; Klinik-Klinik Pratama;

\section{ABSTRACT}

Every employee in a company needs to get satisfaction at work which can also have an impact on improving employee performance. Job satisfaction is an attitude in the form of a reflection of the employee's feelings towards the whole job which consists of various aspects. Someone who is satisfied in their work will have high motivation, commitment to the organization and work participation so that they will continue to improve their performance. The purpose of this study was to find out what are the factors that influence the job satisfaction of pharmacists in the clinics of pratama of Pekanbaru. This study is a descriptive analytic study with a cross-sectional study design using a job satisfaction questionnaire. The sample in this study was a pharmacist who worked in the pratama clinics totaling 55 people taken by simple random sampling technique. The results obtained showed that the most dominant factors affecting the pharmacist's job satisfaction in the clinics of Pratama Kota Pekanbaru were job security (78.91\%), fair treatment $(78.84 \%)$, relationships between colleagues $(78.04 \%)$, salary and promotion $(77.30 \%)$, working conditions $(77.16 \%)$ and relationship with the leader $(76.00 \%)$.

Keywords: Job Satisfaction; Pharmacist; Clinics Pratama

\section{PENDAHULUAN}

Salah satu usaha pembangunan nasional diarahkan kepada tercapainya kemampuan hidup sehat yang bertujuan memajukan kesejahteraan umum dan mencerdaskan kehidupan bangsa. Pembangunan nasional diperlukan kesadaran, kemauan, serta kemampuan untuk hidup sehat bagi setiap penduduk demi tingkat kesehatan yang optimal. Tingkat kesehatan masyarakat yang optimal merupakan modal bagi pelaksanaan pembangunan nasional karena mempunyai arti yang besar untuk pengembangan dan peningkatan kualitas sumber daya manusia, sehingga diperlukan sarana kesehatan yang memadai, meliputi balai pengobatan, pusat kesehatan masyarakat, rumah sakit (umum/swasta), rumah sakit khusus, praktik dokter (umum/spesialis), parktik bidan, apotek, toko obat, pengobatan tradisional, pedagang besar farmasi, dan pabrik obat (modern/tradisonal) (Firmansyah, 2009).

Kepuasan kerja (job satisfaction) merupakan suatu sikap berupa refleksi dari perasaan karyawan terhadap keseluruhan pekerjaan yang terdiri dari bermacam-macam aspek (Spector, 2000). Kepuasan kerja menggambarkan bagaimana konten seseorang dengan pekerjaannya. berikut berbagai faktor yang dapat mempengaruhi tingkat kepuasan kerja seseorang, meliputi tingkat gaji dan tunjangan, kondisi tempat kerja, kepemimpinan dan hubungan sosial, pekerjaan itu sendiri (minat dan tantangan yang dihasilkan pekerjaan). Seseorang yang puas dalam pekerjaannya akan memiliki motivasi, komitmen pada organisasi dan partisipasi kerja yang tinggi sehingga akan terus memperbaiki kinerja mereka (Parvin dan Kabir, 2011).

Apoteker adalah sarjana farmasi yang telah lulus sebagai apoteker dan telah mengucapkan sumpah jabatan apoteker (Anonim, 2009). Dalam hal ini, apoteker harus memahami dan menyadari kemungkinan terjadinya kesalahan pengobatan (medication error) dalam proses pelayanan dan mengidentifikasi, mencegah, serta mengatasi masalah terkait obat (drug related problem). Apoteker juga harus mampu berkomunikasi dengan tenaga kesehatan lainnya dalam menetapkan terapi untuk mendukung penggunaan obat yang rasional (Anonim, 2016). 
Selain harus mempunyai kompetensi sesuai standar dan berkomitmen, seorang apoteker harus memiliki tujuh peran apoteker yang dikenal dengan istilah seven star pharmacist sebagai standar kompetensi apoteker menurut WHO di antaranya adalah apoteker sebagai pemberi pelayanan (care giver), pengambil keputusan (decision maker), mampu berhubungan dengan pasien atau profesi lainnya (communicator), pemimpin (leader), mampu mengelola sumber daya manusia, fisik, anggaran dan informasi (manager), selalu berkeinginan belajar dan membekali dirinya dengan keahlian dan keterampilan yang selalu baru/up-date (life-long learner), dan mampu mendidik dan melatih apoteker generasi mendatang (teacher) (Ahaditomo, 2004).

Menurut Peraturan Menteri Kesehatan Republik Indonesia Nomor 9 tahun 2014, yang dimaksud dengan Klinik adalah fasilitas pelayanan kesehatan yang menyelenggarakan pelayanan kesehatan perorangan yang menyediakan pelayanan medis dasar dan/atau spesialistik. Setiap tenaga medis yang berpraktik di klinik harus mempunyai surat tanda registrasi dan surat izin praktik (SIP) sesuai ketentuan peraturan perundang-undangan. Begitu juga tenaga kesehatan lain yang bekerja di klinik harus mempunyai surat izin sebagai tanda registrasi/ surat tanda registrasi dan surat izin kerja (SIK) atau surat izin praktik apoteker (SIPA) sesuai ketentuan peraturan perundangundangan. Setiap tenaga kesehatan yang bekerja di klinik harus bekerja sesuai dengan standar profesi, standar prosedur operasional, standar pelayanan, etika profesi, menghormati hak pasien, mengutamakan kepentingan dan keselamatan pasien dan juga klinik dilarang mempekerjakan tenaga kesehatan warga negara asing (Anonim, 2014) .

Berdasarkan penelitian Syaiin, (2007) variabel indikator kepuasan pegawai di Klinik Bestari Medan yang mempunyai hubungan signifikan dengan kinerja adalah variabel kepuasan terhadap pekerjaan $(\mathrm{p}=0,046)$, kepuasan terhadap pengawasan $(\mathrm{p}=0,020)$, kepuasan terhadap gaji $(\mathrm{p}=0,016)$ dan kepuasan terhadap hubungan kerabat kerja $(\mathrm{p}=0,109)$. Berdasarkan penelitian Bakhtra et al, (2014) variabel yang menyatakan cukup puas terhadap pekerjaannya dapat dilihat dari total capaian responden, yaitu $75,68 \%$ kondisi kerja. Pada penelitian yang dilakukan oleh Parvin dan Kabir (2011) mengatakan bahwa kondisi kerja cukup dapat mempengaruhi dari kepuasan kerja karyawan, lebih dari $50 \%$ responden sangat menggantungkan kepuasannya pada kondisi kerja.

Tujuan penelitian ini untuk menganalisis faktor-faktor yang mempengaruhi kepuasan kerja apoteker diklinik-klinik pratama Kota Pekanbaru, seperti hubungan dengan antar rekan kerja, perlakuan adil yang didapatkan, kondisi kerja, hubungan karyawan dengan pimpinan, gaji dan promosi yan didapatkan, serta keamanan karyawan saat bekerja

\section{METODE PENELITIAN}

Penelitian ini merupakan penelitian deskriptif analitik secara cross sectional dan penilaian kepuasan kerja diukur dengan menggunakan kuesioner. Populasi dalam penelitian ini adalah 121 Apoteker yang bekerja di Klinik-klinik Pratama Kota Pekanbaru. Sampel pada penelitian ini diambil dengan teknik simple random sampling (acak sederhana). Perhitungan jumlah sampel menggunakan rumus Notoatmodjo (2012) :

$$
\mathrm{n}=\frac{\mathrm{N}}{1+\mathrm{N}\left(d^{2}\right)}
$$

Dimana $\mathrm{n}=$ besar sampel, $\mathrm{N}=\mathrm{jumlah}$ populasi dan $\mathrm{d}=$ tingkat kepercayaan/ketepatan yang ditetapkan (10\%). Sampel dalam penelitian ini sebanyak 55 Apoteker yang bekerja di klinik-klinik pratama Kota Pekanbaru. Faktor-faktor kepuasan kerja yang diamati dalam penelitian ini adalah kondisi kerja, gaji dan promosi, perlakuan adil, keamanan kerja, hubungan antar rekan kerja dan hubungan dengan pimpinan.

\section{HASIL DAN PEMBAHASAN}

Pada hasil penelitian ini diperoleh bahwa responden wanita lebih banyak daripada pria dengan jumlah 45 respoden yaitu $81,8 \%$. Pada kelompok umur, responden 25-35 tahun lebih banyak dengan jumlah 42 responden yaitu $76,4 \%$. Masa kerja terbanyak berkisar antara 1-5 tahun dengan jumlah 33 responden yaitu 60,0\%. Gaji terbanyak dengan jumlah < Rp 3.836.229 diperoleh 49 responden yaitu 89,09\% .

Tabel 1. Hasil Analisis Data Sosiodemografi Responden

\begin{tabular}{|c|c|c|c|}
\hline Uraian & Kategori & $\begin{array}{c}\text { Frekuensi } \\
\text { (orang) }\end{array}$ & $\begin{array}{c}\text { Persentase } \\
(\%)\end{array}$ \\
\hline \multirow{2}{*}{$\begin{array}{l}\text { Jenis } \\
\text { kelamin }\end{array}$} & Pria & 10 & $18,2 \%$ \\
\hline & Wanita & 45 & $81,8 \%$ \\
\hline \multirow{3}{*}{ Umur } & $\begin{array}{l}<25 \\
\text { tahun }\end{array}$ & 4 & $7,3 \%$ \\
\hline & $\begin{array}{l}25-35 \\
\text { tahun }\end{array}$ & 42 & $76,4 \%$ \\
\hline & $>35$ tahun & 9 & $16,4 \%$ \\
\hline \multirow{3}{*}{$\begin{array}{l}\text { Masa } \\
\text { kerja }\end{array}$} & $<1$ tahun & 18 & $32,7 \%$ \\
\hline & $1-5$ tahun & 33 & $60,0 \%$ \\
\hline & $>5$ tahun & 4 & $7,3 \%$ \\
\hline \multirow{2}{*}{ Gaji } & $\begin{array}{c}<\mathrm{Rp} \\
3.836 .229\end{array}$ & 49 & $89,09 \%$ \\
\hline & $\begin{array}{c}>\mathrm{Rp} \\
3.836 .229\end{array}$ & 6 & $10,90 \%$ \\
\hline
\end{tabular}

Dari hasil uji validitas dan reliabilitas didapatkan bahwa 30 item pernyataan didalam kuesioner dinyatakan valid dan reliable, sehingga 
kuesioner ini layak digunakan sebagai alat ukur dalam penellitian ini.

Tabel 2. Faktor-Faktor yang Mempengaruhi Kepuasan Kerja berdasarkan Tingkat Capaian Responden terhadap Variabel

\begin{tabular}{clccc}
\hline No & Variabel & $\begin{array}{c}\text { Rata- } \\
\text { rata }\end{array}$ & TCR & Keterangan \\
\hline 1 & $\begin{array}{l}\text { Kondisi } \\
\text { kerja }\end{array}$ & 3,858 & 77,16 & Cukup \\
2 & $\begin{array}{l}\text { Gaji dan } \\
\text { promosi }\end{array}$ & 3,865 & 77,30 & Cukup \\
3 & $\begin{array}{l}\text { Perlakuan } \\
\text { adil }\end{array}$ & 3,942 & 78,84 & Cukup \\
4 & $\begin{array}{l}\text { Keamanan } \\
\text { kerja }\end{array}$ & 3,952 & 78,91 & Cukup \\
5 & $\begin{array}{l}\text { Hubungan } \\
\text { antara } \\
\text { rekan kerja }\end{array}$ & 3,902 & 78,04 & Cukup \\
& $\begin{array}{l}\text { Hubungan } \\
\text { dengan } \\
\text { pimpinan }\end{array}$ & 3,800 & 76,00 & Cukup \\
\hline
\end{tabular}

Pada Tabel 2 diketahui bahwa nilai rata-rata untuk variabel kondisi kerja adalah 3,86 dengan tingkat capaian responden $77,16 \%$, capaian kategori cukup. Hal ini dapat diinterpretasikan bahwa berdasarkan persepsi responden, pada umumnya kondisi kerja responden di Klinik hanya mencapai kategori cukup puas. Dalam penelitian yang dilakukan oleh Parvin dan Kabir (2011) mengatakan bahwa kondisi kerja cukup dapat mempengaruhi dari kepuasan kerja karyawan. Lebih dari 50\% responden sangat menggantukan kepuasannya pada kondisi kerja yang ada di sekitar tempat dia bekerja. Menurut Burt dalam Sunyoto (2013), salah satu faktor yang menimbulkan kepuasan kerja yaitu faktor fisik lingkungan kerja. Menurut Badeni (2013), kenyamanan tempat kerja dan ketersediaan berbagai sarana yang dibutuhkan dalam melaksanakan pekerjaan berkaitan dengan penerangan yang cukup, ventilasi yang memberikan kesegaran, kebersihan tempat kerja, dan mudah melihat bahwa aspek-aspek diatas menjadi sumber kepuasan kerja sebab disamping hal tersebut dapat memudahkan dalam pelaksanaan tugas juga menjadi penghargaan yang bersifat nonmateri bagi seseorang.

Berdasarkan Analisa data diperoleh nilai ratarata untuk instrumen gaji dan promosi adalah 3,86 dengan tingkat capaian responden $77.30 \%$ yang berada dalam kriteria cukup. Nilai rata-rata tersebut diartikan bahwa persepsi responden yang bekerja di Klinik-Klinik Pratama di Kota Pekanbaru sudah memiliki gaji yang cukup puas. Menurut penelitian yang dilakukan oleh Bakhtra et al (2014) mengatakan bahwa Gaji yang diterima oleh Apoteker yang bekerja di apotek yang ada di kota Padang bersifat signifikan dan berpengaruh positif terhadap kepuasan kerja Apoteker di apotek.
Perolehan gaji yang diterima oleh Apoteker berada dalam kriteria baik dengan rata-rata jawaban responden sebesar $72,79 \%$.

Hasil penelitian ini konsisten dengan penelitian yang dilakukan oleh Khamlub et al (2013) yang menunjukkan bahwa kesempatan untuk maju atau promosi merupakan faktor yang dapat menyebabkan kepuasan kerja. Pada perolehan nilai rata-rata untuk variabel perlakuan adil adalah 3,94 dengan capaian responden sebesar $78,84 \%$ yang berada dalam kriteria cukup, hal ini dapat diinterpretasikan bahwa berdasarkan presepsi responden faktor perlakuan adil hanya mencapai kategori cukup. Hal Ini berarti responden yang bekerja diklinik-klinik pratama Kota Pekanbaru masih merasakan adanya kebutuhan untuk perbaikan.

Dalam penelitian yang dilakukan oleh Bakhtra et al (2014), sebanyak $76,72 \%$ responden yaitu Apoteker yang bekerja di apotek di kota Padang merasa nyaman dengan pekerjaan yang dilakukannya, dalam penelitian yang dilakukan oleh Parvin dan Kabir (2011), perlakuan adil dirasakan oleh lebih dari setengah jumlah total sampel yaitu $60,40 \%$.

Perolehan nilai rata-rata untuk instrumen keamanan kerja adalah 3,95 dengan tingkat capaian responden adalah $78.91 \%$ yang berada dalam kurang. Hal ini dapat diinterpretasikan bahwa berdasarkan persepsi responden keamanan kerja diklinik hanya mencapai kategori cukup baik. Ini berarti responden yang bekerja diklinik-klinik Pratama Kota Pekanbaru masih merasakan sangat memerlukan perbaikan keamanan kerja mereka.

Dalam penelitian yang telah dilakukan oleh Parvin dan Kabir (2011) menyatakan bahwa lebih dari $50 \%$ karyawan merasa aman dalam melakukan pekerjaannya, adanya asusansi jaminan keamanan bila terjadi kesalahan atau kecelakaan dalam melakukan pekerjaan di Industri farmasi. Dalam penelitian yang dilalakukan oleh Bakhtra et al (2014) menyatakan bahwa cukup merasa aman dalam melakukan pekerjaan dengan total jawaban yang diberikan Apoteker sebesar $64,13 \%$ dan yang tidak merasa setuju telah merasakan aman dalam melakukan pekerjaanya sebanyak $35,87 \%$.

Berdasarkan hasil penelitian, diperoleh nilai rata-rata untuk instrumen hubungan dengan dan antara rekan kerja adalah 3,90 dengan tingkat capaian responden $78.04 \%$ yang berada dalam kriteria cukup. Hal ini dapat diinterpretasikan bahwa berdasarkan persepsi responden hubungan dengan dan antara rekan kerja di Klinik hanya mencapai kategori cukup baik. Ini berarti responden yang bekerja di Klinik kota Pekanbaru masih merasakan adanya kebutuhan untuk perbaikan hubungan antara rekan kerja. Dalam penelitian yang dilakukan oleh Parvin dan Kabir (2011) bahwa rekan kerja sangat berpengaruh terhadap peningkatan tingkat kepuasan kerja dengan $80 \%$ responden menjawab puas dengan rekan kerjanya. Dalam penelitian yang 
dilakukan oleh Bakhtra et al (2014) mengatakan bahwa $76,32 \%$ merasa terdapatnya pengaruh dari rekan kerja.

Hasil perolehan nilai rata-rata kepuasan kerja untuk variabel hubungan dengan pimpinan adalah 3,80 dengan tingkat capaian responden $76 \%$ yang berada dalam kriteria cukup. Hal ini dapat diinterpretasikan bahwa berdasarkan persepsi responden hubungan dengan pimpinan diklinik hanya mencapai kategori cukup baik. Ini berarti responden yang bekerja diklinikklinik pratama Kota Pekanbaru masih merasakan adanya kebutuhan untuk perbaikan hubungan dengan pimpinan di klinik.

Sejalan dengan penelitian yang dilakukan oleh Astuti (2009) menyatakan bahwa karyawan merasa hubungan mereka dengan pimpinan terbatas (tidak bersahabat), karyawan merasa kurangnya evaluasi dari pimpinan pada setiap pekerjaan yang mereka lakukan dan karyawan merasa imbalan dan sangsi terhadap pekerjaan mereka tidak sepadan/sebanding dengan apa yang telah mereka lakukan terhadap pekerjaan mereka.

Hasil penelitian ini berbanding terbalik dengan penelitian Bakhtra et al (2014), yang menunjukkan bahwa 73,92\% Apoteker merasa puas terhadap pimpinannya karena pimpinan selalu memberikan motivasi dalam melakukan pekerjaan, pimpinan yang baik, komunikasi yang berjalan lancar serta adanya pengawasan dari hasil kerja. Ada beberapa hal yang harus diperhatikan dalam hubungan dengan pimpinan adalah menjaga silatrahmi dan komunikasi serta bersikap demokrasi terhadap bawahan di apotek.

Siagian (2001) menyatakan bahwa karyawan akan puas bekerja pada suatu organisasi tertentu karena atasannya baik kepadanya artinya kepuasan kerjanya bersumber pada perilaku positif dari atasan langsung. Hastuti (2009) bahwa kesesuaian perilaku pemimpin terhadap tingkat kematangan karyawan berpengaruh terhadap kepuasan kerja yang pada akhirnya meningkatkan prestasi kerja karyawan dalam rangka pelaksanaan efektivitas organisasi. Ruvendi (2005) menemukan hubungan dan pengaruh signifikan antara variabel kepemimpinan dengan kepuasan kerja pegawai.

\section{KESIMPULAN}

Berdasarkan hasil Total Capaian Responden (TCR) dapat disimpulkan bahwa kepuasan kerja apoteker yang bekerja di klinik-klinik pratama Kota Pekanbaru masih dalam kategori cukup puas, dari ke-6 faktor-faktor kepuasan kerja tersebut diurutkan faktor yang paling dominan mempengaruhi kepuasan kerja, yaitu keamanan kerja $(78,91 \%)$, perlakuan adil $(78,84 \%)$, hubungan antar rekan kerja $(78,04 \%)$, gaji dan promosi $(77,30 \%)$, kondisi kerja $(77,16 \%)$ dan hubungan dengan pimpinan $(76,00 \%)$.

\section{SARAN}

Disarankan kepada peneliti selanjutnya untuk melihat faktor-faktor yang mempengaruhi kepuasan kerja terhadap kinerja apoteker dalam bidang pengelolaan obat dan pelayanan kefarmasian. Disaranakan kepada Pemilik Sarana Klinik agar dapat lebih memperhatikan kepuasan kerja apoteker yang bekerja diklinik dengan memperhatikan faktor kondisi kerja apoteker, gaji dan promosi yang diberikan kepada apoteker, perlakuan adil, keamanan kerja apoteker, hubungan apoteker dengan rekan kerja dan hubungan dengan pimpinan.

\section{DAFTAR PUSTAKA}

Ahaditomo. 2004. Standar Kompotensi Farmasis Indonesia. ISFI. Jakarta.

Anonim, 2009. Keputusan Kongres Nasional XVII/2009 Ikatan Sarjan Farmasi Indonesia Nomor 006 tentang Kode Etik Apoteker Indonesia. Keputusan Kongres Nasional XVII/2009 Ikatan Sarjan Farmasi Indonesia. Jakarta.

Anonim. 2014. Peraturan Menteri Kesehatan Republik Indonesia Nomor 9 Tahun 2014 tentang Klinik. Menteri Kesehatan Republik Indonesia. Jakarta.

Anonim. 2016. Peraturan Menteri Kesehatan Republik Indonesia Nomor 73 Tahun 2016 tentang Standar Pelayanan Kefarmasian di Apotek. Menteri Kesehatan Republik Indonesia. Jakarta.

Astuti, H. W. 2009. Meningkatkan Keefektifan Pemimpin Guna Meningkatkan Kepuasan Kerja Karyawan di Dinas Pendidikan Propinsi Daerah Istimewa Yogyakarta. JMK, 7(3): 79-93.

Bakhtra, D. D. A. 2014. Analisis Faktor-Faktor yang mempengaruhi Kepuasan Kerja Apoteker yang Bekerja di Apotek Kota Padang. Tesis. Universitas Andalas. Padang.

Badeni, M. A. 2013.Kepemimpinan dan Perilaku Organisasi. CV Alfabeta. Bandung.

Firmansyah, M. 2009. Tata Cara Mengurus Perizinan Usaha Farmasi dan Kesehatan. Transmedia Pustaka: Jakarta.

Hastuti, M. W. 2009. Pengaruh Kepemimpinan Situasional Terhadap Prestasi Kerja Karyawan Dalam Rangka Pelaksanaan Efektivitas Organisasi. Buletin Daha.

Khamlub, S., Rashid, M.H.O. dan Sarker, M.A.B., Hirosawa, T. Outavong, P. dan Sakamoto, J. 2013. Job Satisfaction of Health Care Workers at Health Centers in Vientiane Capital and Bolikhamsai Province, Lao PDR. Nagoya Journal Medical Science: 75 (4): 233241.

Notoatmodjo, S., 2012, Metodologi Penelitian Kesehatan. Rineka Cipta, Jakarta.

Parvin, M. M. dan Kabir, N. M. M. 2011. Factors Affecting Employee Job Satisfaction of Pharmaceutical Sector. Australian Journal of Business and Management Research. 1(9): 113-123.

Ruvendi, R. 2005. Imbalan dan Gaya Kepemimpinan Pengaruhnya Terhadap Kepuasan Kerja Karyawan Balai Besar Industri Hasil Pertanian Bogor. Jurnal Ilmiah Binaniaga, 1(1) :17-26

Siagian, S. 2001. Manajemen Sumber Daya Manusia. Jakarta: Bumi Aksara.

Spector, P.E. 2000. Industri dan Organisasi Psychology Research and Practice Secound Edition. United State of America : John Wiley dan Sons Inc. 
Jurnal Penelitian Farmasi Indonesia 9(2), Desember 2020

ISSN : 2302-187X

$e$-ISSN 2656-3614

Sunyoto, D. 2013. Teori, Kuesioner, dan Proses Analisis Data Perilaku Organisasional. CAPS (Center for Academic Publishing Service). Yogyakarta.

Syaiin, S. 2007. Pengaruh Kepuasan Kerja Terhadap Kinerja Pegawai Klinik Spesialis Bestari Medan. Tesis. Universitas Sumatera Utara. Medan. 